\title{
Minimum Tillage and in situ Mulch Increasing the Population and Biomass of Earthworms Under Mung Bean Cultivation on Ultisol Soil
}

\author{
Septi Nurul Aini ${ }^{*}$, Sri Yusnaini ${ }^{1}$, Tunsiyah ${ }^{2}$ and Ainin Niswati ${ }^{1}$ \\ ${ }^{1}$ Department of Soil Science and ${ }^{2}$ Department of Agrotechnology, Faculty of Agriculture, \\ Lampung University Jl. Prof. Soemantri Brodjonegoro, No. 1, Bandar Lampung 32145 \\ *e-mail:septi.nurulaini@gmail.com
}

Received July 22, 2019; Revised September 3, 2019; Accepted 24 September, 2019

\begin{abstract}
Earthworms are important soil biota that can be used as an indicator of soil fertility. Soil tillage systems and application of organic mulch will affect the activity of earthworms. This research was aimed to study the effect of tillage systems and the application of in situ mulch, and their interactions on the population and the biomass of earthworms. The study was conducted from April to July 2017 at the Integrated Field Laboratory, Faculty of Agriculture, University of Lampung. The study was arranged in a Randomized Block Design (RBD) in a factorial treatment with two factors. The first factor was the tillage system which consisted of the minimum tillage and the intensive tillage. The second factor was the application of in situ mulch, which consisted of the application of $0 \mathrm{Mg}$ ha $^{-1}$ or without mulch and the application of $5 \mathrm{Mg} \mathrm{ha}^{-1}$ in situ mulch. The data obtained were tested for homogeneity of variance with the Bartlett Test and its additivity with the Tukey Test. Data were further analyzed for the analysis of variance and for the LSD's Test at the level of 5\%. The relationship between soil temperature, soil moisture content, soil organic-C and soil $\mathrm{pH}$ with population and biomass earthworm was tested by correlation test. The results showed that the earthworm population and the earthworm biomass at $80 \mathrm{DAP}$ in the minimum tillage was higher than that of the intensive tillage. The earthworm population for all detected planting stages (before tillage, $40 \mathrm{DAP}$ and $80 \mathrm{DAP}$ ) with the of application of $5 \mathrm{Mg} \mathrm{ha}^{-1}$ in situ mulch was higher than that of the application of no mulch. There is no interaction between the tillage system and the application of in situ mulch at 0 DAP, 40 DAP, and 80 DAP. The genus of earthworms found in all treatment plots was genus Pheretima under the family of Megascolecidae.
\end{abstract}

Keywords: Earthworms, in situ mulch, soil tillage system

\begin{abstract}
ABSTRAK
Cacing tanah merupakan biota tanah penting yang dapat dijadikan indikator kesuburan tanah. Perlakuan sistem olah tanah dan aplikasi mulsa organik akan mempengaruhi aktivitas cacing tanah. Penelitian ini bertujuan untuk mempelajari pengaruh sistem olah tanah dan aplikasi mulsa in situ, dan interaksi antara keduanya terhadap populasi dan biomassa cacing tanah. Penelitian dilaksanakan pada April sampai dengan Juli 2107 di Laboratorium Lapang Terpadu, Fakultas Pertanian, Universitas Lampung, dengan menggunakan Rancangan Acak Kelompok (RAK) yang disusun secara faktorial dengan dua faktor perlakuan. Faktor pertama yaitu sistem olah tanah (T) yang terdiri dari olah tanah minimum $\left(\mathrm{T}_{0}\right)$ dan olah tanah intensif. Faktor kedua yaitu aplikasi mulsa in situ terdiri dari tanpa mulsa $0 \mathrm{Mg} \mathrm{ha}^{-1}$ dan aplikasi mulsa in situ $5 \mathrm{Mg} \mathrm{ha}^{-1}$. Data yang diperoleh diuji homogenitas ragamnya dengan Uji Bartlett dan aditivitasnya dengan Uji Tukey. Data dianalisis dengan analisis ragam dan dilanjutkan dengan Uji BNT pada taraf $5 \%$. Hubungan antara suhu tanah, kadar air tanah, C-organik tanah dan $\mathrm{pH}$ tanah dengan populasi dan biomassa cacing tanah diuji dengan uji korelasi. Hasil penelitian menunjukkan bahwa populasi cacing tanah (80 HST), biomassa cacing tanah (80 HST) pada perlakuan olah tanah minimum lebih tinggi dibandingkan dengan olah tanah intensif $\left(\mathrm{T}_{1}\right)$. Populasi cacing tanah (sebelum olah tanah,40 HST dan $80 \mathrm{HST}$ ) pada perlakuan aplikasi mulsa in situ $5 \mathrm{Mg} \mathrm{ha}^{-1}\left(\mathrm{M}_{1}\right)$ lebih tinggi dibandingkan dengan tanpa aplikasi mulsa in situ. Tidak terdapat interaksi antara perlakuan sistem olah tanah dan aplikasi mulsa in situ pada pengamatan sebelum olah tanah, sebelum olah tanah,
\end{abstract}


40 HST, dan 80 HST. Terdapat 1 genus cacing tanah yang didapat dari hasil identifikasi, yaitu famili Megascolecidae genus Pheretima.

Kata Kunci: Cacing tanah, mulsa in situ, sistem olah tanah

\section{INTRODUCTION}

Soil tillage is a mechanical manipulation of the land to create soil conditions to be good for plant growth. However, according to Utomo (2004), a continuous tillage would have a negative impact on the soil which caused the damage of soil stucture that was either to a direct mechanical destroy or due to the significant loss of the soil organic matter that lead to a break in the soil aggreagate. The loss of soil organic matter in the same time will affects the existence of soil biota. Therefore, soil minimum tillage is highly recommended as one of the soil conservation treatment to be applied in crop farmings.

In preparing land for crop plantation, mulch application is highly recommended. Materials for mulch can come from plant residues and weeds in the previous planting season which is known as in situ mulch. The organic materials applied as mulch can protect the soil from direct sparks of raindrops, suppress weed growth around plant roots and create microclimates that support plant growth (Utomo 2012).

Earthworms are important soil biota that can be used as indicators of soil fertility. Yusnaini et al. (2008) reported that different land use system caused different in earthworm population and biomass. In soil, earthworms represent the largest component of the animal biomass and are commonly termed as ecosystem engineers (Blouin et al. 2013). Earthworms play an important role in improving soil physical properties, namely in the decomposition of fresh organic matter and mixing the organic decay with soil particles, so that the soil particles will be aggregated and hence will improve soil structure (Buck et al. 1999 ). Earthworms also improve soil aeration and improving soil porosity by making holes. In addition, earthworms can improve nutrient availability by their role in the process of decomposition and mineralization of organic matter (Edwards and Lofty 1977; Edwards and Bohlen 1996; Lemtiri et al. 2014).

The combination of tillage and in situ mulch systems was expected to improve soil quality which can be indicated by the presence of earthworms. Therefore, this study was conducted to determine whether the tillage system and application of organic mulch would affect the population and biomass of earthworms on mung bean (Vigna radiata L.) cultivation.

\section{MATERIALS AND METHODS}

\section{Study Site}

This research was conducted from April 2017 to July 2017 at the Integrated Field Laboratory of the Faculty of Agriculture, University of Lampung. The experimental site was located at Gedungmeneng at about 5022'10" south latitude and $105^{\circ} 14^{\prime} 38^{\prime \prime}$ east longitude. The experimental plot was having silty clay soil. The soil was slightly acidic ( $\mathrm{pH}$ of 6.4 ) and low in organic carbon $(2.25 \%)$ and in available$\mathrm{P}$ (7.2 ppm) (Dermiyati et al. 2015). Identification of earthworms and analysis of soil samples was carried out at the Soil Science Laboratory, Faculty of Agriculture, University of Lampung.

\section{Reserch Design}

This study was designed using a Randomized Block Design (RBD) arranged in factorial with two treatment factors. The first factor was a tillage system consisting of minimum tillage $\left(\mathrm{T}_{0}\right)$ and intensive tillage $\left(T_{1}\right)$. While the second factor was the application of in situ mulch (M) consisting of application of $0 \mathrm{Mg} \mathrm{ha}^{-1}$ or without mulch $\left(\mathrm{M}_{0}\right)$ and application of $5 \mathrm{Mg} \mathrm{ha}^{-1}$ in situ mulch $\left(\mathrm{M}_{1}\right)$.

The land was divided into 16 experimental plots in accordance with the treatment with the plot size was of $3 \mathrm{~m} \times 4 \mathrm{~m}$. In situ mulch of the litter from previous planting season was applied at the rate of $5 \mathrm{Mg} \mathrm{ha}^{-1}$. All experimental plots were fertilized by compound fertilizer $\left(15 \% \mathrm{~N}, 15 \% \mathrm{P}_{2} \mathrm{O}_{5}, 15 \% \mathrm{~K}_{2} \mathrm{O}\right)$ of $200 \mathrm{~kg} \mathrm{ha}^{-1}$.

Planting was done by making a planting hole, where each planting hole contains 3-4 seeds of mung bean. The spacing used was $30 \mathrm{~cm} \times 70 \mathrm{~cm}$. Plant maintenance included planting, fertilizing, watering, and weeding

\section{Population and Biomass of Earthworms Enumeration}

Earthworm extraction was begun by marking a land area of $25 \mathrm{~cm} \times 25 \mathrm{~cm}$ with plastic straps followed by digging of the soil inside with a depth of $0-10 \mathrm{~cm}, 10-20 \mathrm{~cm}$ and $20-30 \mathrm{~cm}$. The earthworm 
population was observed from each layer using hand sorting method or by manually separating worms from the soil one by one. The population of earthworms was calculated by the following formula:

Population of earthworms $=\underline{\text { Total of adult earthworm }+ \text { juvenile earthworm }}$ sample plot area $\left(\mathrm{m}^{2}\right)$

After the earthworm population was calculated then all the collected earthworms were weighed to obtain the earthworm biomass with the following formula:

Weight of adult earthworm $(\mathrm{g})+$ juvenile earthworm $(\mathrm{g})$

$$
\text { sample plot area }\left(\mathrm{m}^{2}\right)
$$

\section{Taxonomic Identification of Earthworms}

Large or adult earthworms were washed and weighed and then put into a closed tube containing $70 \%$ alcohol to identify the taxonomy. The identification of earthworms was carried out in the laboratory based on the morphological characteristics according to a guideline (Edwards and Lofty 1977) to identify earthworms based on body parts such as the setae, the mouth type, the clitelium position and the number of segments.

\section{Measurement of Selected Soil Parameters}

Some soil characteristic were analyzed as to support in data interpretation. The parameters measured were soil water content (\%) using the Gravimetric Method, soil temperature $\left({ }^{\circ} \mathrm{C}\right)$ during earthworm sampling using a soil thermometer, organic-C (\%) using the Walkey and Black Method, and soil $\mathrm{pH}$ using the Electrometric Method.

\section{Statistical Analysis}

The data were tested for the homogeneity with the Bartlett Test and the additivity of the data with the Tukey Test. If the hypothesis were fulfilled, then a analysis of variance (ANOVA) was carried out. The mean of the main values was tested by the Least Significance Different (LSD) test at the level of $5 \%$. The relationship between soil water content, soil temperature, soil organic-C and soil $\mathrm{pH}$ with the population and biomass of earthworms was carried out by correlation tests.

\section{RESULTS AND DISCUSSION}

\section{Population and Biomass of Earthworms}

Population and biomass of earthworms and summary of the statistical analysis of the data are presented in Table 1. The results show that the tillage system $(\mathrm{T})$ has a significant effect on the earthworm population at 80 DAP while the application of in situ mulsa (M) has a significant effect on the earthworm population at before tillage, 40 DAP and 80 DAP. There was no interaction between tillage systems and in situ mulch applications $(\mathrm{T} \times \mathrm{M})$ on the earthworm population. According to Hanafiah et al. (2005), soil that are rich in organic matter will be inhabited by more soil biota, among the biota are the earthworms. The increasing earthworm biomass is an indication of the growth of the earthworm population which will be good if there are of enough nutrients from organic matter and if the soil condition is suitable for the growth of earthworms (Siddique et al.2005). Gonzalez and Zou (1999) found that earthworm

Table 1. Effects of the tillage system and application of mulch in situ on the population and biomass of earthworms in the observations before tillage, 40 DAP and 80 DAP.

\begin{tabular}{|c|c|c|c|c|c|c|}
\hline \multirow{3}{*}{ Treatment } & \multicolumn{6}{|c|}{ Observation Variable } \\
\hline & \multicolumn{3}{|c|}{ Earthworm Population (individuals $\mathrm{m}^{-2}$ ) } & \multicolumn{3}{|c|}{ Earthworm Biomass $\left(\mathrm{g} \mathrm{m}^{-2}\right)$} \\
\hline & BT & 40 DAP & 80 DAP & BT & 40 DAP & $80 \mathrm{DAP}$ \\
\hline $\mathrm{T}_{0} \mathrm{M}_{0}$ & 132 & 148 & 128 & 8.64 & 8.80 & 12.40 \\
\hline $\mathrm{T}_{0} \mathrm{M}_{1}$ & 196 & 276 & 244 & 17.00 & 16.52 & 15.20 \\
\hline $\mathrm{T}_{1} \mathrm{M}_{0}$ & 144 & 148 & 44 & 10.20 & 10.40 & 2.40 \\
\hline $\mathrm{T}_{1} \mathrm{M}_{1}$ & 216 & 216 & 116 & 21.40 & 13.60 & 9.60 \\
\hline Variance & \multicolumn{6}{|c|}{ F-Value and Significantly } \\
\hline $\mathrm{T}$ & $0.31^{\mathrm{tn}}$ & $1.31^{\mathrm{tn}}$ & $11.32 *$ & $0.45^{\text {th }}$ & $0.02^{\mathrm{tn}}$ & $10.10 *$ \\
\hline M & $5.58 *$ & $13.99 *$ & $8.90 *$ & $4.81^{\mathrm{tn}}$ & $1.14^{\mathrm{tn}}$ & $4.15^{\mathrm{tn}}$ \\
\hline $\mathrm{T} \times \mathrm{M}$ & $0.02^{\mathrm{tn}}$ & $1.31^{\mathrm{tn}}$ & $0.49^{\mathrm{tn}}$ & $0.10^{\mathrm{tn}}$ & $0.20^{\mathrm{tn}}$ & $0.80^{\mathrm{tn}}$ \\
\hline
\end{tabular}

Description: $\mathrm{DAP}=$ day after planting; $\mathrm{BT}=$ before tillage; $\mathrm{T}_{0}=$ minimum tillage; $\mathrm{T}_{1}=$ intensive soil processing; $\mathrm{M}_{0}=$ without mulch in situ; $\mathrm{M}_{1}=$ application of mulch in situ $5 \mathrm{t} \mathrm{ha}^{-1} ; \mathrm{T}=$ soil processing system; $\mathrm{M}=$ application of mulch in situ; $\mathrm{T}$ x $\mathrm{M}=$ interaction between the tillage system and mulch application in situ; $\mathrm{tn}=$ no significant effect on the level of $5 \%$; $*$ significant effect on the level of $5 \%$. 
Table 2. Effect of the tillage system on the population and biomass of earthworms in 80 DAP.

\begin{tabular}{ccc}
\hline \multirow{2}{*}{ Treatment } & Earthworm Population (individuals $\left.\mathrm{m}^{-2}\right)$ & Earthworm Biomass $\left(\mathrm{g} \mathrm{m}^{-2}\right)$ \\
\cline { 2 - 3 } & $80 \mathrm{DAP}$ & $80 \mathrm{DAP}$ \\
\hline Minimum tillage $\left(\mathrm{T}_{0}\right)$ & $186 \mathrm{a}$ & $13.80 \mathrm{a}$ \\
Intensive tillage $\left(\mathrm{T}_{1}\right)$ & $80 \mathrm{~b}$ & $6.00 \mathrm{~b}$ \\
\hline LSD 0.05 & 71 & 5.55 \\
\hline
\end{tabular}

Note: $\mathrm{DAP}=$ day after planting; the number followed by the same letter is not significantly different from the LSD test at the level of $5 \%$.

Table 3. Effect of the application of in situ mulch on the earthworm population in observations before tillage, 40 DAP and 80 DAP.

\begin{tabular}{cccc}
\hline \multirow{2}{*}{ Treatment } & \multicolumn{3}{c}{ Earthworm Population (individuals $\mathrm{m}^{-2}$ ) } \\
\cline { 2 - 4 } & BT & 40 DAP & 80 DAP \\
\hline Without mulch in situ application $\left(\mathrm{M}_{0}\right)$ & $138 \mathrm{~b}$ & $148 \mathrm{~b}$ & $86 \mathrm{~b}$ \\
Application of mulch in situ $5 \mathrm{Mg} \mathrm{ha}^{-1}\left(\mathrm{M}_{1}\right)$ & $206 \mathrm{a}$ & $246 \mathrm{a}$ & $180 \mathrm{a}$ \\
\hline LSD 0.05 & 65 & 59 & 71 \\
\hline
\end{tabular}

Note: $\mathrm{DAP}=$ day after planting; $\mathrm{BT}$ = before tillage; the number followed by the same letter is not significantly different from the LSD test at the level of $5 \%$.

density rapidly decreases with litter removal and increases with litter addition in two plant communities.

The results of the LSD's test (Table 2) show that the population and biomass of earthworms were higher in the plot treated with minimum soil tillage compared to the plot of intensive tillage. Minimum soil tillage is reffered to mechanical treatment of soil, such as plowing the soil, that is only carried out at minimum intensity. In many practices a minimum tillage consist of only activity of preparing planting holes so that it does not cause much changes in the physical properties of the soil except at the holes. Whereas in intensive soil tillage land preparation is carried out by plowing the soil throughout the surface down to certain depth and completed by leveling the soil surface so that it can cause soil particles and pores to be more exposed to the sunlight and oxygen and hence will undergo more evaporation of water. The more exposure of the soil particles and agregates will in turn result in an acceleration of soil organic matter (SOM) decomposition (Utomo 2012). According to Chan (2001), the declines in earthworm population often reported in conventionally tilled soils are associated with undesirable changes in the soil environmental conditions resulting from excessive tillage. The same phenomenon was also reported by Niswati et al. 2018, in long-term no-tillage system in sugarcane plantation

The results of the LSD's test (Table 3) show that the population and biomass of earthworms were higher in the plot treated with $5 \mathrm{Mg}^{-1}$ in situ of mulch compared to the plot of no mulch application. It was Jayanthi et al. (2014) stated that soil moisture was very influential on the growth of earthworms because the earthworm's body contains $75-90 \%$ water, so that low soil moisture would cause earthworms to dehydrate and caused death in earthworms. Plant remains or litter found on the ground are an energy source for earthworms (Dwiastuti 2012). According to Martin and Lavelle (1992) canopy leaf litter has been suggested to be the major resource or decomposer communities including earthworms due to high carbohydrate content. Earthworms can carry plant residue or litter into their burrows, then they remove their dirt (vermicompost) on the surface of the soil.

\section{Physical and Chemical Properties of Soil under Mung Beans (Vigna radiata L.) Cropping}

The results of soil water content analysis (Table 4) show that at before tillage the water content ranged from $33.13 \%-35.99 \%$, at 40 DAP ranged from $29.27 \%-31.09 \%$, and at 80 DAP ranged from $29.92 \%-33.06 \%$. Earthworms are soil fauna that utilizes water from the surrounding environment because earthworms must maintain the moisture of the cuticle so that gas exchange can take place. Soil moisture plays a role in maintaining the activity of earthworms, because the earthworm's body contains water about $75-90 \%$ of its body weight. In inappropriate environmental conditions, earthworms will move to another place and remove some of the 


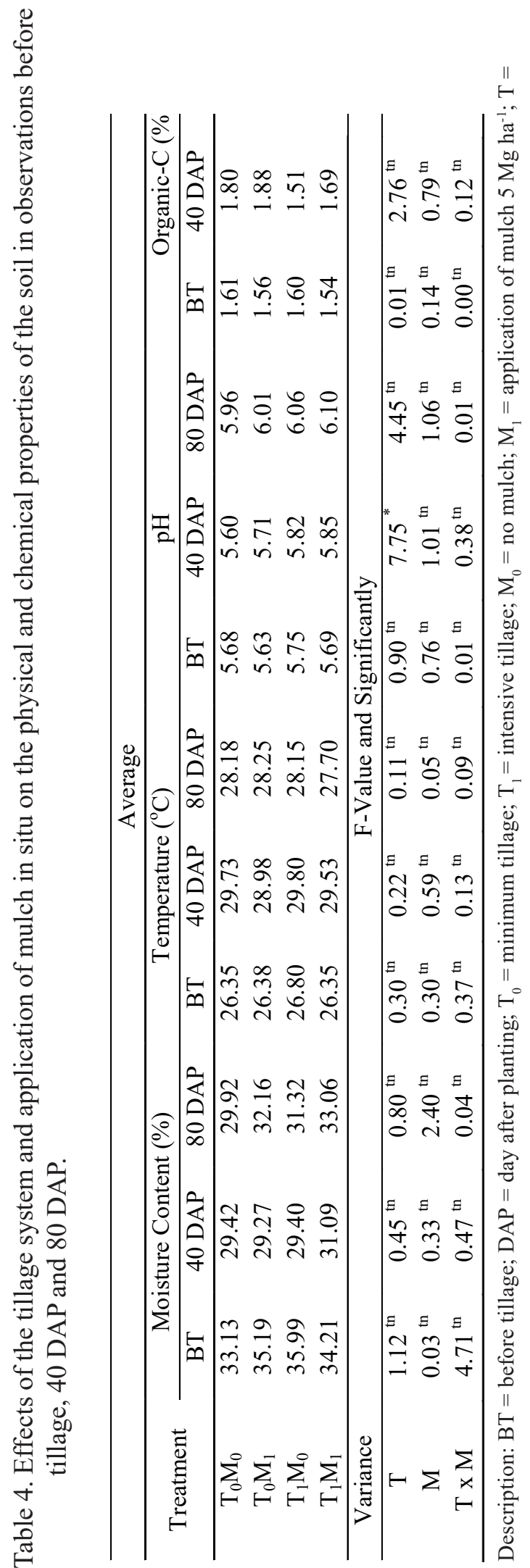

liquid from the body into the soil so that they can life longer. The strategy of earthworms to be able to survive in very dry conditions is by emptying the contents of their digestion and rolling up their bodies to hide in burrows. Earthworms can go into diapause in the subsoil when the topsoil is too dry for their activities, are well fitted to tolerate seasonal drought (El-Duweini and Ghabbour 1965).

The results of the soil temperature measurement (Table 4) on show that at before tillage the soil temperature ranged from $26.35^{\circ} \mathrm{C}-26.80^{\circ} \mathrm{C}$, at 40 DAP ranged from $28.98{ }^{\circ} \mathrm{C}-29.80^{\circ} \mathrm{C}$ and at 80 DAP ranging from $27.70{ }^{\circ} \mathrm{C}-28.25^{\circ} \mathrm{C}$. The ideal soil temperature for the growth of earthworms and cocoon hatching ranges from $15-25^{\circ} \mathrm{C}$ (Lowe and Butt 2005; Handayanto and Hairiah 2009). The soil temperature of above $25{ }^{\circ} \mathrm{C}$ is still suitable for earthworms but must be balanced with adequate humidity. Good humidity for growth and reproduction of earthworms is around 15\% - 30\% (Yulipriyanto 2010).

Soil organic-C contents show that at before tillage the soil organic-C ranged from $1.54 \%-1.61 \%$, at 40 DAP ranged from $1.51 \%-1.88 \%$ and at 80 DAP ranged from $1.73 \%-1.98 \%$. Organic-C describes the abundance of organic matter in the soil, and abundant organic matter in the soil can attract earthworms to gather because organic matter is an energy source for earthworms for their life (Lavelle et al. 2001).

The soil $\mathrm{pH}$ shows that at before tillage the soil $\mathrm{pH}$ ranged from 5.63 to 5.75 , at 40 DAP ranging from 5.60 to 5.85 and at 80 DAP $5.96-6.10$. Based on the results it was found that the tillage system (T) had a significant effect on soil $\mathrm{pH}$ at 40 DAP. The results of LSD's test (Table 5) show that the treatment of the intensive tillage system $\left(\mathrm{T}_{1}\right)$ had a higher soil $\mathrm{pH}$ compared to the minimum tillage $\left(\mathrm{T}_{0}\right)$. However, the soil $\mathrm{pH}$ values of the two tillage systems were still in the same criteria, which was rather acidic (5.65 - 6.5) (Suhariyono and Menry 2005). Generally, earthworms can develop well at neutral soil $\mathrm{pH}$, or slightly alkaline. The $\mathrm{pH}$ between $6.0-7.2$ is the optimum $\mathrm{pH}$ for bacterial activity to forage or nutrition (Hanafiah et al. 2005). McCallum et al. (2016) reported that total earthworm

Table 5. The effect of the tillage system on $\mathrm{pH}$ in mung bean (Vigna radiata L.) cultivation 40 DAP.

\begin{tabular}{cc}
\hline Treatment & $\mathrm{pH}$ \\
\hline Minimum tillage $\left(\mathrm{T}_{0}\right)$ & $5.65 \mathrm{~b}$ \\
Intensive tillage $\left(\mathrm{T}_{1}\right)$ & $5.83 \mathrm{a}$ \\
\hline LSD 5\% & 0.15 \\
\hline
\end{tabular}

Note: the number followed by the same letter is notsignificantly different from the LSD test at the level of 5\%.. 
Table 6. The results of the correlation test between supporting variables with the population of earthworms (individualsm $\mathrm{sm}^{-2}$ ) and earthworm biomass $\left(\mathrm{g} \mathrm{m}^{-2}\right)$ in mung bean plants (Vigna radiata $\mathrm{L}$.).

\begin{tabular}{|c|c|c|c|c|c|c|}
\hline \multirow{3}{*}{ Variables } & \multicolumn{6}{|c|}{ Correlation Coefficient (r) } \\
\hline & \multicolumn{3}{|c|}{ Earthworm Population (individuals $\mathrm{m}^{-2}$ ) } & \multicolumn{3}{|c|}{ Earthworm Biomass $\left(\mathrm{g} \mathrm{m}^{-2}\right)$} \\
\hline & BT & 40 DAP & 80 DAP & BT & 40 DAP & 80 DAP \\
\hline Moisture Content (\%) & $0.14^{\mathrm{tn}}$ & $-0.02^{\text {tn }}$ & $0.09^{\mathrm{tn}}$ & $0.25^{\text {tn }}$ & $-0.49^{\text {tn }}$ & $0.13^{\mathrm{tn}}$ \\
\hline Temperature $\left({ }^{\circ} \mathrm{C}\right)$ & $0.14^{\mathrm{tn}}$ & $-0.18^{\mathrm{tn}}$ & $0.22^{\text {tn }}$ & $-0.33^{\text {tn }}$ & $-0.41^{\mathrm{tn}}$ & $0.17^{\mathrm{tn}}$ \\
\hline Organic-C (\%) & $0.25^{\mathrm{tn}}$ & $0.42^{\mathrm{tn}}$ & $0.35^{\text {th }}$ & $0.08^{\text {tn }}$ & $0.24^{\mathrm{tn}}$ & $0.34^{\mathrm{tn}}$ \\
\hline $\mathrm{pH}$ of soil & $0.10^{\mathrm{tn}}$ & $0.09^{\mathrm{tn}}$ & $-0.19^{\mathrm{tn}}$ & $-0.26^{\mathrm{tn}}$ & $0.18^{\mathrm{tn}}$ & $0.33^{\text {tn }}$ \\
\hline
\end{tabular}

Note: $\mathrm{BT}=$ before tillage; DAP $=$ day after planting; $\mathrm{tn}=$ not significant at level $5 \%$.

abundance increased with increasing soil $\mathrm{pH}$ and earthworm densities were very low in soils below $\mathrm{pH}$ 4.5.

Based on the correlation test (Table 6), it was found that soil water content, soil temperature, soil organic $\mathrm{C}$ and soil $\mathrm{pH}$ in each planting stage did not correlate significantly with the population and biomass of earthworms. It was assumed that the treatment of tillage systems and application of mulch in the 6th planting season had no significant effect on the soil environment under mung bean cultivation, so it did not have an affect to the population and biomass of earthworms. This can also be caused by the short duration of the study and the high $\mathrm{C} / \mathrm{N}$ ratio of the used in situ mulch, that was corn litter with $\mathrm{C} / \mathrm{N}$ ratio of 82 (Nuraida and Mochtar 2006) and Imperata grass with $\mathrm{C} / \mathrm{N}$ ration of 100 (Sembiring 2014), so that it was likely that in situ mulch has not been completely decomposed and has not affected the water content, temperature, organic- $\mathrm{C}$ and $\mathrm{pH}$ of the soil.

\section{Earthworm Identification}

Based on the determination of earthworm identification proposed by Hanafiah et al. (2005), and the description of earthworms proposed by Edwards and Lofty (1977) it was found that the type of earthworm in the mung bean (Vigna radiata L.) field was an earthworm with the family group of Megascolicidae, of the Pheretima genus. The Pheretima genus earthworm has $155 \mathrm{~mm}$ long features, annular clitellum (reproductive tool) located in the 14 segment (Figure 1a), the form of prostomium (mouthpiece) of type epilobus (Figure 1b), and patterned setae (fine hair) perisetin (Figure 1c). Jayanthi et al. (2014), reported that the earthworms Pheretima sp. has a body length ranging from $150-185 \mathrm{~mm}$, a diameter of 5-6 mm, with several segments between 125 - 145, dorsal color purplish brown, ventral pale or whitish gray. The color of the anterior tip is yellowish-brown and the posterior tip is pale brown/yellow. Epilobus-type prostomium, the clit yet is annular and does not thicken, the segments are clear, have setae of the perisetin type, male genital holes in segment 18 and female genital holes in segment 14 . The earthworm of the genus Pheretima belongs to the family Megascolecidae, this worm has the characteristics of clitellum shaped like a ring located in segments 14-16, has setae with a perisetin pattern, and the

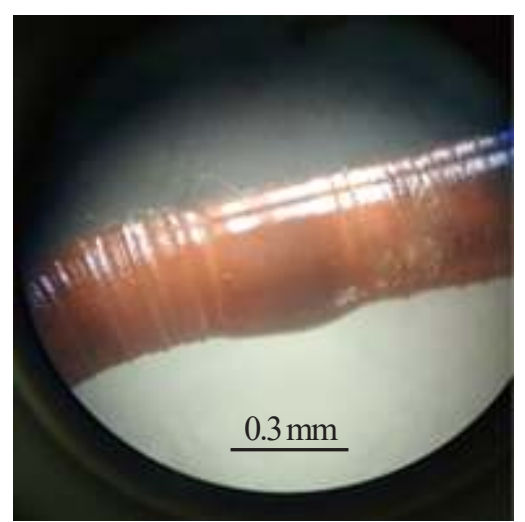

(a)

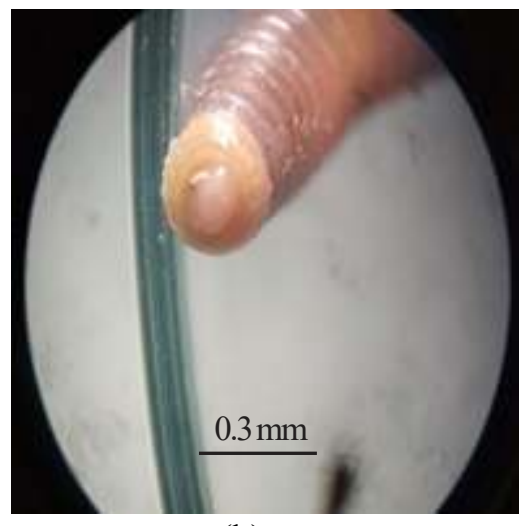

(b)

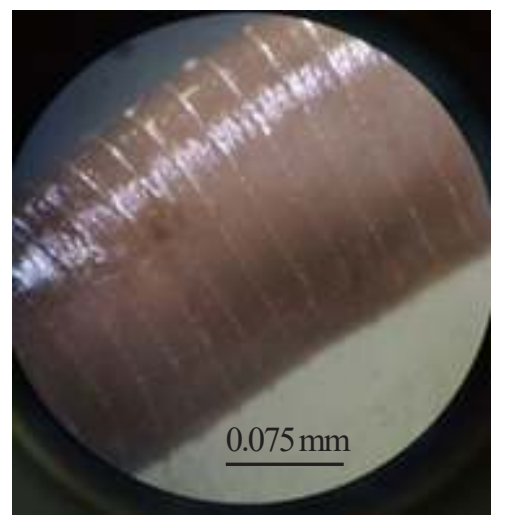

(c)

Figure 1. Morphology of earthworm found this research (a) Clitelum Pheretima, (b) Prostomium type epilobus, (c) Setae perisetin. 
prostomium type is epilobus (Edwards and Lofty 1977; Sims and Easton 1972).

Adult earthworms identified were obtained from plots with a minimum tillage system treatment (T0). Earthworms are abundant on the surface of the earth with a depth of $0-10 \mathrm{~cm}$ compared to a depth of $10-20 \mathrm{~cm}$ and $20-30 \mathrm{~cm}$, so it can be said that the earthworms belong to the epigeic worm group. This is caused by the top layer of soil is a layer of soil that is rich in organic material, so that more earthworms in that layer. Hanafiah et al. (2005) reported that the distribution of organic matter in the soil affects earthworms, because in poor soil organic matter only a few earthworms are found. Organic matter plays an important role as a source of energy for soil fauna. According to Yulipriyanto (2010), earthworms of the epigeic group are earthworms that live on the surface of the soil (topsoil). Epigeic earthworms are found in soils with a depth of $\pm 5 \mathrm{~cm}$. Epigeic worms have a high reproductive ability, fast movement ability, have pigmentation in the dorsal part, eat litter, and have limited ability to dig holes.

\section{CONCLUSIONS}

The earthworm population (80 DAP) and the earthworm biomass (80 DAP) at the minimum tillage were higher than intensive tillage. The earthworm population (before tillage, $40 \mathrm{DAP}$, and $80 \mathrm{DAP}$ ) with the application of mulch in situ $5 \mathrm{Mg} \mathrm{ha}^{-1}$ was higher than without the application of mulch in situ. There was no interaction between the tillage system and the application of mulch in situ on the observation before tillage, $40 \mathrm{DAP}$, and 80 DAP. There was one genus of earthworms was identified, namely the family of Megascolecidae genus Pheretima.

\section{ACKNOWLEDGEMENTS}

We are particularly grateful to Prof. Dr. Ir. Jamalam Lumbanraja, M.Sc. and Prof. Dr. Ir. Dermiyati, M.Agr.Sc., who participated in giving advice and criticism. We also thank the Integrated Field Laboratory of the Faculty of Agriculture, University of Lampung that has provided a place in carrying out this research.

\section{REFERENCES}

Blouin M, ME Hodson, EA Delgado, G Baker, L Brussaard, KR Butt, J Dai, L Dendooven, G Peres, JE Tondoh, D Cluzeau and JJ Brun . 2013. A review of earthworm impact on soil function and ecosystem service. Eur J Soil Sci 64: 161-182.
Chan KY. 2001. An overview of some tillage impacts on earthworm population abundance and diversityimplications forfunctioning in soils. Soil Till Res 57: 179-191.

Buck C, M Langmaack and S Schrader. 1999. Nutrient content of earthworm cast influenced by different mulch types. Eur J Soil Biol 35: 23-30.

Dermyati, J Lumbanraja, IS Banuwa, S Triyono, O Maulida and D Agsari. 2015. Application of Organonitrofos and Inorganic Fertilizer on Cassava (Manihot Esculenta Crantz) in Ultisol Soil. J Trop Soils 20: 167-172.

Dwiastuti S. 2012. Kajian tentang kontribusi cacing tanah dan perannya terhadap lingkungan kaitannya dengan kualitas tanah. Seminar Nasional IX Pendidikan Biologi FKIP UNS. Universitas Sebelas Maret. Surakarta. 448-451. (in Indonesian).

Edwards CA and JR Lofty. 1977. Biology of Earthworms. A Haalseed Press Book. New York. 255 p.

Edwards CA and PJ Bohlen. 1996. Biology and Ecology of Earthworms. Chapman and Hall, London, $426 \mathrm{p}$.

El-Duweini AK and SI Ghabbour. 1965. Population density and biomass of earthworms in different types of Egyptian soils. The J Appl Ecol 2: 271-287.

Gonzalez G and X Zou. 1999. Plant and litter influences on earthworm abundance and community structure in a tropical wet forest. Biotropica 31: 486-493.

Handayanto E and K Hairiah. 2009. Biologi Tanah. Landasan Pengelolaan Tanah. Yogyakarta, Pustaka Adiputra. 191 p. (in Indonesian).

Hanafiah KA, A Napoleon and N Ghoffar. 2005. Ekologi dan Mikrobiologi Tanah. Rajawali Press. Jakarta. 157 p. (in Indonesian).

Jayanthi SR, Widhiastuti and E Jumilawaty. 2014. Komposisi komunitas cacing tanah pada lahan pertanian organik dan anorganik di Desa Ray Kecamatan Berastagi Kabupaten Karo. J Biotik 2: 1-76. (in Indonesian).

Lavelle P, E Barros, E Blanchart, G Brown, T Desjardins, L Mariani and JP Rossi. 2001. SOM management in the tropics: why feeding the soil macrofauna? Nutr Cycl Agroecosys. 61: 53-6.

Lemtiri A, G Colinet, T Alabi, D Cluzeau, L Zirbes, É Haubruge and F Francis. 2014. Impacts of earthworms on soil components and dynamics. Biotechnol Agron Soc Environ 18: 121-133.

Lowe CN and KR Butt. 2005. Culture techniques for soil dwelling earthworms:a review. Pedobiologia 49: 401-413. doi: https://doi.org/10.1016/ j.pedobi.2005.04.005

Martin A and P Lavelle. 1992. Effect of soil organic matter quality on its assimilation by Millsonia anomala, a tropical geophagous earthworm. Soil Biol Biochem 24: 1535-1 539.

McCallum HM, J Wilson, D Beaumont, R Sheldon, MG O'Brien and Park K. 2016. A role for liming as a conservation intervention? earthworm abundance is associated with higher soil $\mathrm{pH}$ and foraging activity of a threatened shorebird in upland grasslands. Agr Ecosyst Environ 223: 182-189. doi: http://dx.doi.org/10.1016/j.agee.2016.03.005. 
Niswati A, S Yusnaini, M Utomo, Dermiyati, MAS Arif, S Haryani and N Kaneko. 2018. Long-term organic mulching and no-tillage practice increase population and biomass of earthworm in sugarcane plantation. IOP Conf Series: Earth Environ Sci 215: 012034. doi: 10.1088/1755-1315/215/1/012034

Nuraida and AN Mochtar. 2006. Laju dekomposisi jerami padi dan serasah jagung dengan pemberian inokulum dan pupuk hijau. Penelitian Pertanian Tanaman Pangan 25: 185-189. (in Indonesian).

Sembiring FA, S Yusnaini, H Buchari and A Niswati. 2014. Pengaruh sistem olah tanah terhadap populasi dan biomassa cacing tanah pada lahan bekas alangalang yang ditanami kedelai. J Agrotek Trop 2: 475481. (in Indonesian).

Siddique J. AA Khan, I Hussain and S Akhter 2005. Growth and reproduction of earthworm (Eisenia fetida) in different organic media. PakJ Zool 37: 211-214.

Sims RW and EG Easton. 1972. A numerical revision of the earthworm genus Pheretima auct. (Megascolecidae: Oligochaeta) with the recognition of new genera and an appendix on the earthworms collected by the Royal Society North Borneo Expedition. Biol J Linn Soc 4: 169-268.
Suhariyono G and Menry Y. 2005. Analisis karakteristik unsur-unsur dalam tanahdi berbagai lokasi denan menggunakan XRF. Prosidin PPIPDIPN.Yogyakarta, 12 Juli 2005. 197-206 hlm. (in Indonesian).

Utomo M. 2004. Olah tanah konservasi untuk budidaya jagung berkelanjutan. Prosiding Seminar Nasional IX Budidaya Pertanian Olah Tanah Konservasi.Gorontalo, 6-7 Oktober, 2004. pp.18-35. (in Indonesian).

Utomo M. 2012. Tanpa Olah Tanah Teknologi Pengolalan Pertanian Lahan Kering. Lembaga Penelitian Universitas Lampung. Bandar Lampung. 110 p. (in Indonesian).

Yulipriyanto H. 2010. Biologi Tanah dan Strategi Pengelolaannya. Graha Ilmu. Yogyakarta. 258 p. (in Indonesian).

Yusnaini S, A Niswati, MAS Arif and M Nonaka. 2008. The changes of earthworm population and chemical properties of tropical soils under different land use systems. J Trop Soils 13: 131-137. 